\title{
Natural Radioactivity and Excess Lifetime Cancer Risk Associated with Soil in Kargi Area, Marsabit-Kenya
}

\author{
Willis Ougo Aguko, Robert Kinyua, John Gitonga Githiri \\ Physics Department, School of Physical Sciences, College of Pure \& Applied Sciences, Jomo Kenyatta University of Agriculture \\ and Technology, Nairobi, Kenya \\ Email: agukow8@gmail.com, kinyua@fsc.jkuat.ac.ke, githiri@fsc.jkuat.ac.ke
}

How to cite this paper: Aguko, W. O., Kinyua, R., \& Githiri, J. G. (2020). Natural Radioactivity and Excess Lifetime Cancer Risk Associated with Soil in Kargi Area, Marsabit-Kenya. Journal of Geoscience and Environment Protection, 8, 127-143. https://doi.org/10.4236/gep.2020.812008

Received: November 13, 2020 Accepted: December 14, 2020 Published: December 17, 2020

Copyright $\odot 2020$ by author(s) and Scientific Research Publishing Inc. This work is licensed under the Creative Commons Attribution International License (CC BY 4.0).

http://creativecommons.org/licenses/by/4.0/

\begin{abstract}
The main aim of investigating activity concentrations together with distribution of radionuclides naturally in soil from Kargi was to evaluate radiological health hazard together with environmental radioactivity. Research shows radionuclides as one source of exposure due to radiation with detrimental effects health wise for populations found in areas considered high background radiation. After collecting 117 soil samples from the area, analysis was done in order to measure their natural radioactivities due to ${ }^{40} \mathrm{~K},{ }^{232} \mathrm{Th}$ and ${ }^{226} \mathrm{Ra}$ radionuclides. Measurements method of gamma spectrometry employing a high purity germanium (HPGe) detector was employed basically to evaluate the radiological hazard of radioactivities. For ${ }^{40} \mathrm{~K},{ }^{232} \mathrm{Th}$ and ${ }^{226} \mathrm{Ra}$, mean calculated activities were $353.19 \pm 110.07,7.98 \pm 3.98$ and $7.37 \pm 2.60 \mathrm{~Bq} \cdot \mathrm{kg}^{-1}$ respectively. Mean values of absorbed and effective dose rates, external and internal hazard indices together with radium equivalent activity were $23.82 \pm$ $6.59 \mathrm{nGy} \cdot \mathrm{h}^{-1}$ and $0.14 \pm 0.04 \mathrm{mSv} \cdot \mathrm{y}^{-1}, 0.12 \pm 0.03$ and $0.14 \pm 0.04$ and $45.90 \pm$ $12.65 \mathrm{~Bq} \cdot \mathrm{kg}^{-1}$ respectively. Comparing with approved global values, the values were found to be below the given global limits. Evidence of involvement of metasomatic activity of the radioelements or fractionation during weathering is seen as calculations give a higher value Th/U. Excess cancer risk, calculated from the samples showed lower values as compared to global standard values hence minimal chance of getting cancer disease. The area is safe from cancer causing radionuclides.
\end{abstract}

\section{Keywords}

Kargi-Marsabit, Nuclear Science, Gamma-Ray Spectrometry, Lifetime Cancer Risk, Activity 


\section{Introduction}

Radioactive elements found in rocks, soil, water, air, and in food from the earth make their way in our bodies when we breathe in air or eat foods which contain them. These naturally occurring radio isotopes such as carbon-14, potassium-40, thorium-232, uranium-238, polonium-218 and tritium (hydrogen-3) expose us to radiation from within our bodies.

Exposure to radiation is injurious to living tissues owing to its ionizing power in matter. This ionization can directly destroy living cells directly, by breaking up the chemical bonds of key biological molecules like DNA, or indirectly, by creating chemical radicles from water molecules in the cells, which can chemically attack biological molecules (UNSCEAR, 1993). Somehow, these molecules are mended by use of natural biological procedures; effectiveness of this mending however depends on the size of damage. Obviously, if cell repair is not properly done or not repaired at all, the cell then may suffer either of these possible fates (Cember, 1996):

1) Cell demise

2) Cell impairment leading to somatic effects that are physical effects suffered by the irradiated person like cancer disease.

3) Genetic mutation, considered a permanent alteration of the cell and which is passed to the later generations.

The presence of radionuclides in natural environment has been noticed always. Wherever universally present in little amounts in building materials and earth, thorium together with uranium series, together with potassium $40\left({ }^{40} \mathrm{~K}\right)$ are considered leading natural donors to external exposure from $\gamma$-radiation. (UNSCEAR, 2008).

Potassium, uranium and thorium radioactive elements together with any of their decay outcomes like radon and radium are examples of Naturally Occurring Radioactive Materials (NORM) considered long-lived. These elements have always existed in the atmosphere and earth's crust. NORM issue relates to radon exposure in homes, particularly those built on granitic ground. By using building materials with relatively high activity concentration of ${ }^{226} \mathrm{Ra}$ and building techniques that stipulate the influx of radon from the ground e.g. well insulated housing, the radiation dose to the population dose is still further increased (Aguko et al., 2013).

Approximation of the radiation dose distribution is key in gauging the health risk to a populace and serves as a reference point for registering changes in environmental radioactivity owing to anthropogenic activities (Obed et al., 2005).

Exposure to radiation for a long period of time is presumed to have some probabilities of cancer causing disease, thus everyone is at risk of contracting cancer. An additional risk that a person might have of contracting cancer disease due to long time exposure to materials causing cancer disease is called excess lifetime cancer risk (ELCR) (Qureshi et al., 2014).

For outdoor occupation evaluating the terrestrial gamma dose rate, estimation 
of the natural radioactivity level is very important for geological samples, usually determined from the ${ }^{40} \mathrm{~K},{ }^{232} \mathrm{Th}$ and ${ }^{226} \mathrm{Ra}$ contents (UNSCEAR, 2000). Activity concentrations of ${ }^{40} \mathrm{~K},{ }^{232} \mathrm{Th}$ and ${ }^{226} \mathrm{Ra}$ in collected soils have been estimated mainly by gamma ray spectrometry, although the fission track registration technique has also been used for the analysis of uranium concentration of these samples (Singh et al., 2005). They found the absorbed dose rate as found in air, calculated the gamma dose rate from concentration of radionuclides of ${ }^{40} \mathrm{~K},{ }^{232} \mathrm{Th}$ and ${ }^{226} \mathrm{Ra}$ from which they deduced the effective dose the inhabitants receive annually.

Health facilities found within and around Kargi have continuously reported a number of cancer (disease) cases together with deaths year in year out hence prompting this research work. The main aim of investigating activity concentrations together with distribution of radionuclides naturally in soil from this area was to gauge radiological health hazard together with environmental radioactivity.

\section{Research Area, Sampling, Materials and Measurements}

\subsection{Research Area}

\section{Study Area}

Kargi, found between longitudes $37^{\circ} 32^{\prime} 34^{\prime \prime} \mathrm{E}$ and $37^{\circ} 36^{\prime} 07^{\prime \prime} \mathrm{E}$ and latitudes $2^{\circ} 28^{\prime} 37^{\prime \prime} \mathrm{N}$ and $2^{\circ} 31^{\prime} 15^{\prime \prime} \mathrm{N}$ is a small village in Marsabit, Kenya covering an area of approximately $31.26 \mathrm{~km}^{2}$ as seen in Figure 1. Bordering Kargi is Chalbi,

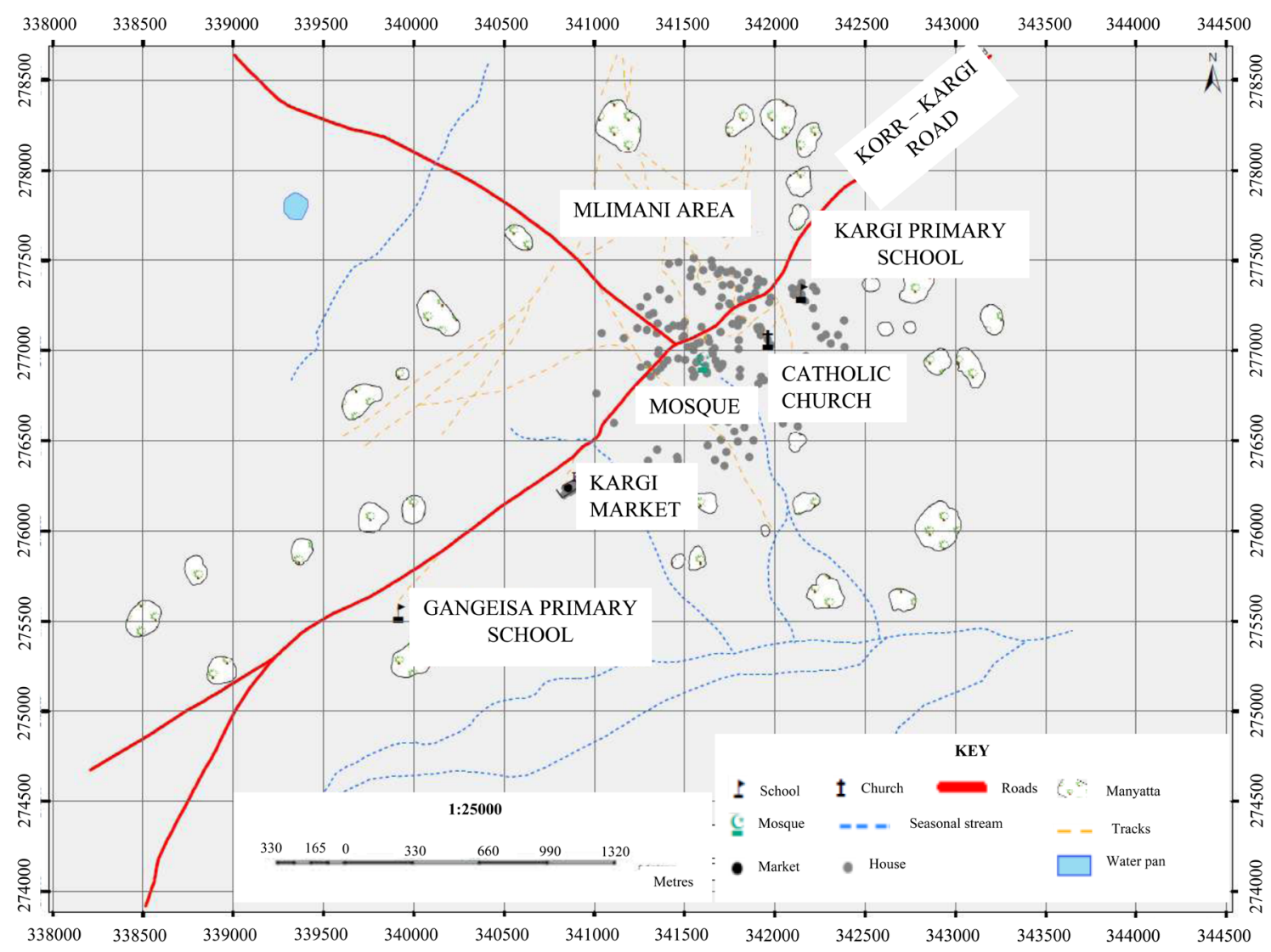

Figure 1. Map showing Kargi area (Survey of Kenya, 2017, modified). 
Gabra and Samburu.

\subsection{Sampling and Materials}

\section{Sample Collection and Preparation}

A total of 117 samples were collected according to the internationally established experience (Tzortzis \& Tsertos, 2004). Systematic grid sampling method, generally considered unbiased was employed during sampling. The area was divided in to a regular square, and samples collected from the nodes (IAEA TECDOC 486, 2019) (Figure 2).

The EPA (1995), describes that the factors which determine the distance between sampling locations in the grid are the size of the area to be sampled and the number of samples. For each sample collection, an area of about $0.5 \mathrm{~km} \mathrm{x} 0.5$ $\mathrm{km}$ was marked to help get a good representation of the area. To avoid samples contamination from top soil containing leaves and other contaminations, samples were collected 10 centimetres from the surface (Monika et al., 2010). These samples were packed and clearly marked before transporting to Nairobi.

Rock together with soil samples were sun dried after their collection, separately crushed in powder form to help homogenize them. Sieving the crushed

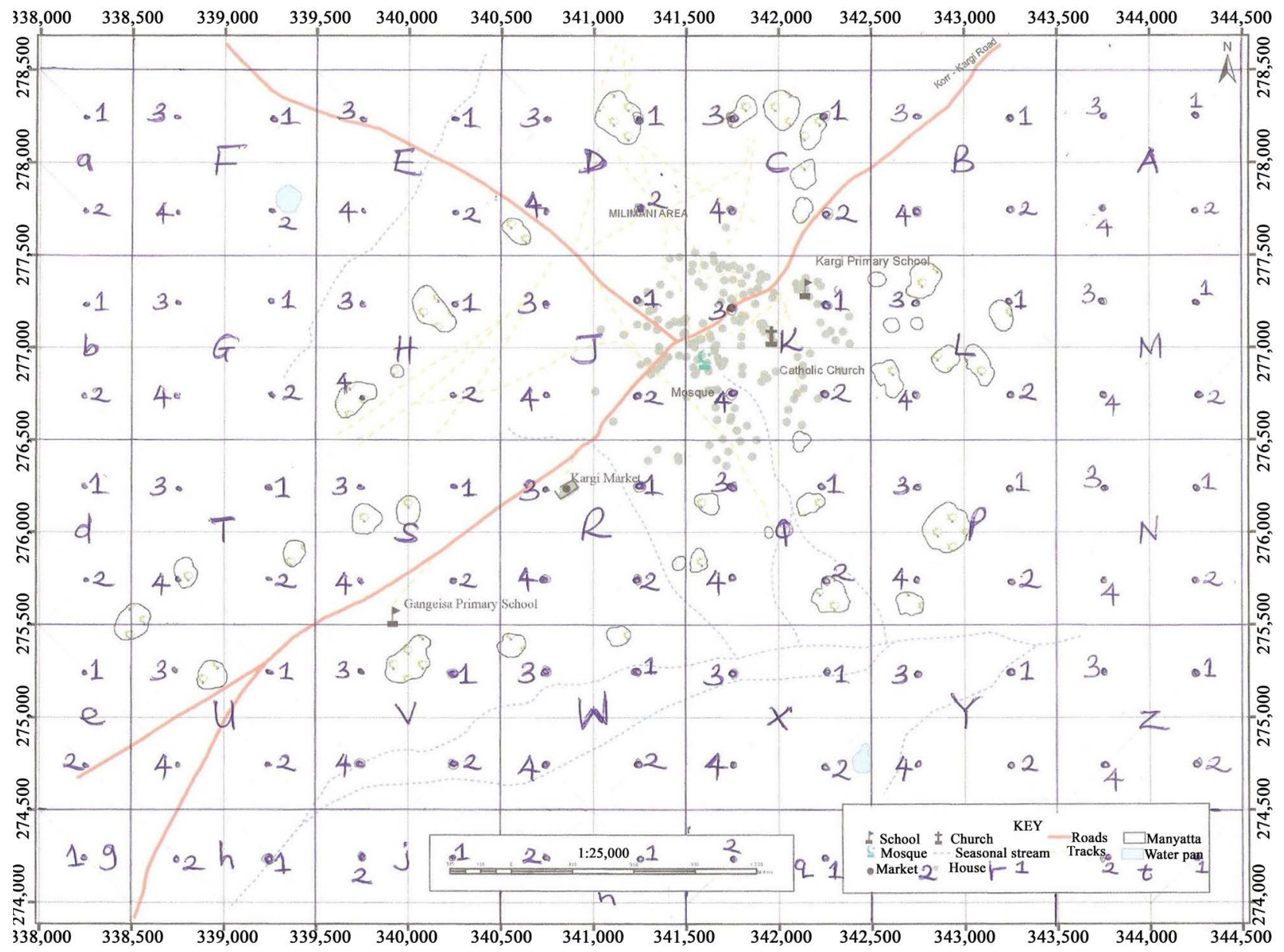

Figure 2. Sample collection plan for Kargi area (Survey of Kenya, 2017, modified). 
powder through a $0.6 \mathrm{~mm}$ mesh sieve was done, oven dried for 24 hours at $100^{\circ} \mathrm{C}$ to remove water completely from these samples. Crushed powder samples were individually weighed, parked in a special marked containers (plastic) before being closed tightly for about 4 weeks which was enough time to allow ${ }^{238} \mathrm{U}$ and ${ }^{232} \mathrm{Th}$ to reach secular equilibrium with their daughters before measurement of radioactivity (Hassan et al., 2016).

\subsection{Measurement}

\subsubsection{Measurement of Activity Concentration of Natural Radionuclide and Absorbed Doses}

A high-purity germanium (HPGe) gamma-ray detector, $76 \mathrm{~mm}$ outside diameter, active volume of $144 \mathrm{~mm}^{3}$ with an efficiency and a resolution of $31.6 \%$ and $1.8 \mathrm{keV}$ respectively was used for measurement of activity concentrations. individual sample was put in a marinelli beaker of $500 \mathrm{~cm}^{3}$, filled up to same IAEA standard reference soil level (RGK-1, RGU-1 and RGTh-1) and then positioned in a lead shielded detector, adopting 22,000 - 62,000 seconds as counting time. Soil sample reference standards from International Atomic Energy Agency (IAEA) (RGU-1, RGTh-1, RGK-1 and IAEA-375 soil) were used for method validation together with calibration of spectrometer using Maestro software (IAEA, 2003).

A comparative method was then employed to compute the activity concentration of each radionuclide. There were five notable gamma lines, ${ }^{40} \mathrm{~K}$ line, ${ }^{214} \mathrm{P}_{\mathrm{b}}$ and ${ }^{214} \mathrm{~B}_{\mathrm{i}}$ lines from ${ }^{238} \mathrm{U}$ and ${ }^{212} \mathrm{P}_{\mathrm{b}}$ and ${ }^{228} \mathrm{~A}_{\mathrm{c}}$ lines from ${ }^{232} \mathrm{Th}$ for each sample. $\mathrm{A}$ gamma line of $1461 \mathrm{keV}$ gave activity of ${ }^{40} \mathrm{~K}$, the activity of ${ }^{238} \mathrm{U}$ from $352 \mathrm{keV}$ and $609 \mathrm{keV}$ gamma lines of ${ }^{214} \mathrm{P}_{\mathrm{b}}$ and ${ }^{214} \mathrm{~B}_{\mathrm{i}}$ respectively and that of ${ }^{232} \mathrm{Th}$ from $238 \mathrm{keV}$ and $912 \mathrm{keV}$ gamma lines of ${ }^{212} \mathrm{P}_{\mathrm{b}}$ and ${ }^{228} \mathrm{~A}_{\mathrm{c}}$ respectively.

\subsubsection{Outdoor External Gamma Dose-Rate ( $\left.D_{\text {out }}\right)$}

The outdoor dose-rates $\left(D_{\text {out }}\right)$ due to $\gamma$-radiations in air, measured $1 \mathrm{~m}$ above surface of ground for even spread of naturally occurring radionuclides $\left({ }^{40} \mathrm{~K}\right.$, ${ }^{232} \mathrm{Th}$ and ${ }^{226} \mathrm{Ra}$ ) were computed based on UNSCEAR 2000 provided guidelines. Assuming that the contributions coming from other naturally occurring radionuclides to be unimportant, then $D_{\text {out }}$ can be computed from:

$$
D_{\text {out }}\left(\mathrm{nGy} \cdot \mathrm{h}^{-1}\right)=\left(0.467 C_{R a}+0.662 C_{T h}+0.043 C_{K}\right)
$$

where, $C_{k}, C_{R a}$ and $C_{T h}$ are the average activities of potassium, radium and thorium respectively in the sample and $\mathrm{nGy} \cdot \mathrm{h}^{-1}$ (nano Gray per hour) is the unit of the absorbed dose rates $(D)$.

\subsubsection{Indoor External Gamma Dose Rate $\left(D_{i n}\right)$}

European Commission, 1999 gives a formula for calculating indoor external dose rate as:

$$
D_{\text {in }}\left(\mathrm{nGy} \cdot \mathrm{h}^{-1}\right)=\left(0.92 C_{R a}+1.1 C_{T h}+0.081 C_{K}\right)
$$

where, $C_{k} C_{R a}$ and $C_{T h}$ are the average activities of potassium, radium and thorium respectively in the sample and nGy.h -1 (nano Gray per hour) is the unit of the 
Table 1. Sample collection plan, average activity concentration $\left(\mathrm{Bq} \cdot \mathrm{l}^{-1}\right)$ and Radium equivalent $\left(\mathrm{Bq} \cdot \mathrm{l}^{-1}\right)$.

\begin{tabular}{|c|c|c|c|c|c|c|}
\hline \multirow{2}{*}{$\begin{array}{l}\text { Sample } \\
\text { area code }\end{array}$} & \multirow{2}{*}{$\begin{array}{c}\text { Number of } \\
\text { samples collected }\end{array}$} & \multirow{2}{*}{$\begin{array}{l}\text { Sampling } \\
\text { area, } \mathbf{k m}^{20}\end{array}$} & \multicolumn{3}{|c|}{ Activity, Bq/kg } & \multirow{2}{*}{$\begin{array}{c}\text { Radium equivalen } \\
\text { activity, }\left(R a_{e q}\right) \text { in } \\
\mathrm{Bq} \cdot \mathrm{kg}^{-1}\end{array}$} \\
\hline & & & ${ }^{232} \mathrm{Th}$ & ${ }^{238} \mathrm{U}$ & ${ }^{40} \mathrm{~K}$ & \\
\hline A & 4 & 1.00 & $4.32 \pm 2.04$ & $5.80 \pm 1.92$ & $276.14 \pm 46.70$ & $33.24 \pm 3.40$ \\
\hline B & 4 & 1.00 & $5.63 \pm 1.86$ & $6.78 \pm 2.25$ & $405.39 \pm 84.53$ & $46.04 \pm 5.52$ \\
\hline $\mathrm{C}$ & 4 & 1.00 & $7.03 \pm 2.29$ & $6.08 \pm 1.23$ & $324.42 \pm 70.37$ & $41.11 \pm 4.75$ \\
\hline $\mathrm{D}$ & 4 & 1.00 & $8.42 \pm 2.23$ & $6.83 \pm 1.59$ & $287.93 \pm 76.28$ & $41.04 \pm 8.04$ \\
\hline $\mathrm{E}$ & 4 & 1.00 & $10.07 \pm 4.31$ & $6.75 \pm 3.02$ & $281.74 \pm 119.85$ & $42.84 \pm 14.55$ \\
\hline $\mathrm{F}$ & 4 & 1.00 & $9.35 \pm 5.51$ & $8.86 \pm 1.60$ & $361.70 \pm 117.59$ & $50.08 \pm 18.37$ \\
\hline G & 4 & 1.00 & $8.96 \pm 3.21$ & $7.77 \pm 1.44$ & $455.26 \pm 101.45$ & $55.64 \pm 7.39$ \\
\hline $\mathrm{H}$ & 4 & 1.00 & $6.97 \pm 3.65$ & $7.89 \pm 1.30$ & $259.89 \pm 54.69$ & $37.86 \pm 6.61$ \\
\hline $\mathrm{J}$ & 4 & 1.00 & $8.43 \pm 0.33$ & $6.30 \pm 1.82$ & $242.56 \pm 89.52$ & $37.03 \pm 7.61$ \\
\hline $\mathrm{K}$ & 4 & 1.00 & $6.84 \pm 1.12$ & $9.75 \pm 5.62$ & $287.13 \pm 98.99$ & $41.64 \pm 13.41$ \\
\hline $\mathrm{L}$ & 4 & 1.00 & $6.62 \pm 2.61$ & $5.93 \pm 0.70$ & $436.01 \pm 40.84$ & $48.96 \pm 6.08$ \\
\hline M & 4 & 1.00 & $6.37 \pm 0.68$ & $5.71 \pm 1.16$ & $330.39 \pm 21.92$ & $40.25 \pm 1.65$ \\
\hline $\mathrm{N}$ & 4 & 1.00 & $9.70 \pm 5.47$ & $6.13 \pm 0.68$ & $308.68 \pm 116.39$ & $43.76 \pm 16.76$ \\
\hline $\mathrm{P}$ & 4 & 1.00 & $2.74 \pm 2.59$ & $6.07 \pm 2.40$ & $349.51 \pm 70.58$ & $36.91 \pm 2.73$ \\
\hline $\mathrm{Q}$ & 4 & 1.00 & $9.70 \pm 3.70$ & $8.51 \pm 2.73$ & $405.47 \pm 155.79$ & $53.60 \pm 17.31$ \\
\hline $\mathrm{R}$ & 4 & 1.00 & $7.49 \pm 2.78$ & $8.72 \pm 2.26$ & $398.65 \pm 33.46$ & $50.13 \pm 6.43$ \\
\hline S & 4 & 1.00 & $6.71 \pm 1.63$ & $7.93 \pm 0.24$ & $330.12 \pm 49.75$ & $42.94 \pm 3.89$ \\
\hline $\mathrm{T}$ & 4 & 1.00 & $10.66 \pm 5.89$ & $10.53 \pm 3.51$ & $425.98 \pm 131.73$ & $58.57 \pm 18.03$ \\
\hline $\mathrm{U}$ & 4 & 1.00 & $8.33 \pm 3.20$ & $7.73 \pm 1.75$ & $380.98 \pm 168.08$ & $48.97 \pm 16.99$ \\
\hline $\mathrm{V}$ & 4 & 1.00 & $8.96 \pm 12.51$ & $6.36 \pm 3.62$ & $440.90 \pm 151.62$ & $53.12 \pm 32.96$ \\
\hline $\mathrm{W}$ & 4 & 1.00 & $6.54 \pm 4.26$ & $6.85 \pm 1.33$ & $450.12 \pm 52.19$ & $50.86 \pm 9.57$ \\
\hline $\mathrm{x}$ & 4 & 1.00 & $9.34 \pm 5.98$ & $9.05 \pm 4.68$ & $380.08 \pm 264.93$ & $51.67 \pm 29.07$ \\
\hline $\mathrm{Y}$ & 4 & 1.00 & $9.31 \pm 5.13$ & $11.96 \pm 2.81$ & $231.27 \pm 86.67$ & $43.07 \pm 11.16$ \\
\hline $\mathrm{Z}$ & 4 & 1.00 & $12.34 \pm 3.14$ & $8.53 \pm 2.09$ & $311.59 \pm 33.34$ & $50.17 \pm 5.64$ \\
\hline $\mathrm{a}$ & 2 & 0.50 & $7.70 \pm 0.86$ & $5.61 \pm 1.61$ & $438.06 \pm 143.71$ & $50.34 \pm 10.68$ \\
\hline $\mathrm{b}$ & 2 & 0.50 & $9.75 \pm 5.96$ & $5.54 \pm 0.32$ & $472.49 \pm 57.64$ & $55.85 \pm 3.77$ \\
\hline $\mathrm{d}$ & 2 & 0.50 & $8.73 \pm 4.47$ & $4.04 \pm 1.05$ & $369.76 \pm 115.25$ & $45.00 \pm 1.44$ \\
\hline e & 2 & 0.50 & $6.98 \pm 0.07$ & $6.78 \pm 1.77$ & $404.28 \pm 82.71$ & $47.89 \pm 8.24$ \\
\hline $\mathrm{g}$ & 1 & 0.25 & $9.89 \pm 0.00$ & $5.75 \pm 0.00$ & $407.13 \pm 0.00$ & $51.24 \pm 0.00$ \\
\hline $\mathrm{h}$ & 2 & 0.50 & $8.65 \pm 0.64$ & $8.58 \pm 2.57$ & $387.28 \pm 42.80$ & $50.76 \pm 6.78$ \\
\hline$j$ & 2 & 0.50 & $9.83 \pm 0.14$ & $6.12 \pm 2.27$ & $372.98 \pm 32.05$ & $48.89 \pm 0.40$ \\
\hline $\mathrm{n}$ & 2 & 0.50 & $6.87 \pm 0.69$ & $7.61 \pm 0.08$ & $333.28 \pm 32.51$ & $43.09 \pm 1.59$ \\
\hline $\mathrm{q}$ & 2 & 0.50 & $5.18 \pm 0.71$ & $6.46 \pm 2.55$ & $286.89 \pm 11.60$ & $35.95 \pm 4.46$ \\
\hline $\mathrm{r}$ & 2 & 0.50 & $8.54 \pm 1.34$ & $4.94 \pm 1.21$ & $324.75 \pm 10.59$ & $42.15 \pm 1.53$ \\
\hline $\mathrm{t}$ & 2 & 0.50 & $8.27 \pm 2.07$ & $8.78 \pm 1.49$ & $259.57 \pm 128.33$ & $40.58 \pm 11.35$ \\
\hline Total & 117 & Average & $8.03 \pm 1.91$ & $7.23 \pm 1.67$ & $354.81 \pm 67.06$ & $46.04 \pm 6.28$ \\
\hline
\end{tabular}


absorbed dose rates (D).

\subsubsection{Radium Equivalent Activity $\left(R a_{e q}\right)$}

Radium equivalent $\left(R a_{e q}\right)$ activity, a weighted sum of ${ }^{40} \mathrm{~K},{ }^{232} \mathrm{Th}$ and ${ }^{226} \mathrm{Ra}$ activities is established on approximation that $13 \mathrm{~Bq} \cdot \mathrm{kg}^{-1}$ of ${ }^{40} \mathrm{~K}, 1 \mathrm{~Bq} \cdot \mathrm{kg}^{-1}$ of ${ }^{238} \mathrm{U}$ and $0.7 \mathrm{~Bq} \cdot \mathrm{kg}^{-1}$ of ${ }^{232} \mathrm{Th}$ produce the similar radiation dose rates. Avwiri et al. (2013) estimates radium equivalent activity as:

$$
R a_{e q}\left(\mathrm{~Bq} \cdot \mathrm{kg}^{-1}\right)=C_{U}+1.43 C_{T h}+0.077 C_{K}
$$

where, $C_{U}, 1.43 C_{T h}$ and $0.077 C_{K}$ are activity concentrations in $\mathrm{Bq} \cdot \mathrm{kg}^{-1}$ or $\mathrm{Bq} \cdot \mathrm{l}^{-1}$ of ${ }^{238} \mathrm{U},{ }^{232} \mathrm{Th}$ and ${ }^{40} \mathrm{~K}$.

\subsubsection{Annual Effective Dose (De)}

Two main classification of annual effective dose are annual outdoor $\left(D_{\text {out }}\right)$ and indoor $\left(D_{\text {in }}\right)$ effective doses respectively. In estimating the yearly effective dose rates, coefficients of conversion from absorbed dose to effective dose of 0.7 $\mathrm{Sv} \cdot \mathrm{Gy}^{-1}$ together with $0.2 \mathrm{~Sv} \cdot \mathrm{Gy}^{-1}$ (UNSCEAR, 2008) proposed outdoor occupancy factor are used. Mustapha (1999) estimates occupancy factors, that is mean time consumed indoor and outdoor as 0.6 and 0.4 respectively. According to UNSCEAR, 2008 the respective global mean outdoor and indoor occupancy factors are 0.2 and 0.8 .

\section{1) Annual outdoor effective dose ( $\left.D e_{\text {out }}\right)$}

In estimating the yearly effective dose $\left(D_{e}\right)$, coefficients of conversion from absorbed dose as measured in air to effective dose $\left(0.7 \mathrm{~Sv} \cdot \mathrm{Gy}^{-1}\right)$ and an outdoor occupancy factor of 0.2 as proposed by UNSCEAR 2008 are used. The following formula therefore gives the effective dose rate:

$$
D e_{\text {out }}\left(\mathrm{mSv} \cdot \mathrm{y}^{-1}\right)=D\left(\mathrm{nGy} \cdot \mathrm{h}^{-1}\right) \times 8760 \mathrm{~h} \cdot \mathrm{yr}^{-1} \times 0.4 \times 0.7 \mathrm{~Sv} \cdot \mathrm{Gy}^{-1} \times 10^{-6}
$$

where,

$\mathrm{mSv} \cdot \mathrm{y}^{-1}$ (milli sieverts per year) is the unit for annual effective dose rate ( $\left.D e\right)$

$\mathrm{nGy} \cdot \mathrm{h}^{-1}$ (nano Gray per hour) is the unit of the absorbed dose rates $(D)$

hy $\cdot r^{-1}$ (hour per year) given by 24 hours (in a day) $\times 365$ days (in a year)

\section{2) Annual indoor effective dose $\left(D e_{i n}\right)$}

This can be taken as that dose a person receives while in the indoor environment and can be computed from formula 5 (UNSCEAR, 2000). Annual indoor effective dose depends on time of stay inside a building, dose factors for conversion together with gamma ray dose existing within buildings.

$$
D e_{i n}\left(\mathrm{mSv} \cdot \mathrm{y}^{-1}\right)=D\left(\mathrm{nGy} \cdot \mathrm{h}^{-1}\right) \times 8760 \mathrm{~h} \cdot \mathrm{yr}^{-1} \times 0.6 \times 0.7 \mathrm{~Sv} \cdot \mathrm{Gy}^{-1} \times 10^{-6}
$$

where,

$\mathrm{mSv} \cdot \mathrm{y}^{-1}$ (milli sieverts per year) is the unit for annual effective dose rate $(D e)$

$\mathrm{nGy} \cdot \mathrm{h}^{-1}$ (nano Gray per hour) is the unit of the absorbed dose rates $(D)$

hy $\cdot \mathrm{r}^{-1}$ (hour per year) given by 24 hours (in a day) $\times 365$ days (in a year)

\subsubsection{Annual Gonadal Equivalent Dose (AGED)}

UNCEAR (2000) considers bone marrow, bone surface cells and gonads to be 
organs of interest due to their radiation sensitivity. $A G E D$ increase has been known to interfere with bone marrow thereby red blood cells causing a cancer disease known as leukemia which is lethal. The $A G E D$ for the inhabitant using such material for building may be evaluated by the following equation (Avwiri et al., 2013):

$$
\operatorname{AGED}\left(\mu \mathrm{Sv} \cdot \mathrm{y}^{-1}\right) C=3.09 C_{U}+4.18 C_{T h}+0.314 C_{K}
$$

\subsubsection{Excess Lifetime Cancer Risk (ELCR)}

Potential carcinogenic effects that are characterized by estimating the probability of cancer incidence in a populace of individuals for a particular lifetime from projected exposures and intakes is called Excess Lifetime Cancer Risk (ELCR). Taskin et al. (2009) and Qureshi et al. (2014) calculates ELCR using Equations (7) and (8).

$$
\begin{aligned}
& E L C R_{\text {in }}=D_{e_{\text {in }}} \times D L \times R F \\
& E L C R_{\text {out }}=D_{e_{\text {out }}} \times D L \times R F
\end{aligned}
$$

where,

$E L C R=$ Excess Lifetime Cancer Risk

$D_{e_{i n}}=$ Annual indoor effective Dose

$D_{e_{\text {out }}}=$ Annual outdoor effective Dose

$D L=$ Average Duration of Life in year $(\approx 70)$

$R F=$ Risk Factor in $\mathrm{Sv}^{-1}$, that is, lethal cancer risk.

For stachostic effects, ICRP (1990) and Taskin et al. (2009) uses RF as 0.05 for public.

\subsubsection{Hazard Indices}

\section{1) Hazard indices for external gamma radiation $\left(H_{e x}\right.$ and $\left.I_{\gamma}\right)$}

Two indices were used in assessing the gamma radiation excess from materials used in building to ensure these materials safety. From the building materials, a hazard index describing the external gamma radiation dose is given as (Beretka \& Mathew, 1985; Raghu et al., 2017):

$$
H_{e x}=\frac{A_{R a}}{370 \mathrm{~Bq} \cdot \mathrm{kg}^{-1}}+\frac{A_{T h}}{259 \mathrm{~Bq} \cdot \mathrm{kg}^{-1}}+\frac{A_{K}}{4810 \mathrm{~Bq} \cdot \mathrm{kg}^{-1}}
$$

where, $A_{R a}, A_{T h}$ and $A_{K}$ are the activity concentrations, in $\mathrm{Bq} \cdot \mathrm{kg}^{-1}$ of Uranium $\left({ }^{238} \mathrm{U}\right)$, Thorium $\left({ }^{232} \mathrm{Th}\right)$ and potassium $\left({ }^{40} \mathrm{~K}\right)$ respectively.

For safe use of building materials, $H_{e x}$ value needs to be less than unity, corresponding to $370 \mathrm{~Bq} \cdot \mathrm{kg}^{-1}$, an upper limit of $R a_{e q}$. In order to substantiate whether European Commission (EC) guidelines for usage of building materials are met, EC proposed an index $\left(I_{\gamma}\right)$ given by:

$$
I_{\gamma}=\frac{A_{R a}}{300}+\frac{A_{T h}}{200}+\frac{A_{K}}{3000} \leq 1
$$

An exception criterion of 0.3 together with an upper limit of $1 \mathrm{mSv} \cdot \mathrm{y}^{-1}$ are the 
two dose criteria used for the gamma dose of construction materials as introduced by European Commission (EC. Many countries put in their control on 1 $\mathrm{mSv} \cdot \mathrm{y}^{-1}$, the upper limit. If exception criterion of 0.3 together with an upper limit of $1 \mathrm{mSv} \cdot \mathrm{y}^{-1}$ is taken into consideration, then $I_{\gamma}$ values ought to be below 0.5 and 1 respectively for materials (cement and brick) used in bulk. For building materials (tiles and board) considered superficial, restricted application should be implemented and $I_{\gamma}$ ought to be below 2 and 6 respectively, supposing values of control of 0.3 and $1 \mathrm{mSv} \cdot \mathrm{y}^{-1}$.

\section{2) Hazard indices for internal alpha radiation ( $H_{\text {in }}$ and $I_{a}$ )}

Alpha $\left(I_{\alpha}\right)$ and internal hazard $\left(H_{i n}\right)$ indices are the two indices used in assessing alpha radiation excess due to radon gas coming from building materials. Raghu et al. (2017) mathematically defines $H_{\text {in }}$ as in equation 11 below and can be used for internal radiation excess consideration owing to ${ }^{222} \mathrm{Rn}$ inhalation together with its short lived decay products from building materials.

$$
H_{\text {in }}=\frac{A_{R a}}{185 \mathrm{~Bq} \cdot \mathrm{kg}^{-1}}+\frac{A_{T h}}{259 \mathrm{~Bq} \cdot \mathrm{kg}^{-1}}+\frac{A_{K}}{4810 \mathrm{~Bq} \cdot \mathrm{kg}^{-1}}
$$

For safe use of materials in building construction, the computed $H_{\text {in }}$ value should be less than unity.

For us to neglect the radiation hazard, values of the indices $\left(H_{e x}, H_{i n}\right)$ as from Equations (9) and (11) respectively must be less than unity (Harb et al., 2010).

Equation (12) gives the quantity $I_{\alpha}$ as:

$$
I_{\alpha}=\frac{A_{R a}}{200} \leq 0.5
$$

The recommended respective values of $I_{\alpha}$ and $I_{\gamma}$ are below 0.5 and 1 (Krieger, 1981; Raghu et al., 2017).

2.3.9. Correlation between ${ }^{238} \mathrm{U}$ and ${ }^{232} \mathrm{Th},{ }^{238 \mathrm{U}}$ and ${ }^{40} \mathrm{~K}$ and ${ }^{232} \mathrm{Th}$ and ${ }^{40} \mathrm{~K}$ According to Avwiri et al. (2013), the elemental concentrations (ppm) of U-238, Th-232 together with percentage potassium can be computed from activity concentrations of Th-232, U-238 together with $\mathrm{K}-40$ in $\mathrm{Bq} \cdot \mathrm{kg}^{-1}$ as measured using the below conversion factors:

$$
\begin{gathered}
\left.1 \mathrm{ppm} \mathrm{Th}=4.06 \mathrm{~Bq} \cdot \mathrm{kg}^{-1} \quad \text { (of } \mathrm{Th}-232\right) \\
\left.1 \mathrm{ppm} \mathrm{U}=12.35 \mathrm{~Bq} \cdot \mathrm{kg}^{-1} \quad \text { (of } \mathrm{U}-238\right)
\end{gathered}
$$

$1 \% \mathrm{~K}=313 \mathrm{~Bq} \cdot \mathrm{kg}^{-1} \quad$ (of K-40) (IAEA Technical Report No. 1363)

Table 2 compares and summerises values of activities of ${ }^{40} \mathrm{~K},{ }^{232} \mathrm{Th},{ }^{226} \mathrm{Ra}$ together with $R a_{e q}$ in soil samples from Kargi to those from similar investigations in other countries.

\section{Results and Discussion}

Calculations give specific activities of ${ }^{238} \mathrm{U}$ and ${ }^{232} \mathrm{Th}$ series as well as ${ }^{40} \mathrm{~K}$, expressed in Bq. $\mathrm{kg}^{-1}$ for samples obtained from Kargi area as summerised in Table 1 . Obtained values for ${ }^{226} \mathrm{Ra},{ }^{232} \mathrm{Th},{ }^{40} \mathrm{~K}$ together with $\mathrm{Ra}_{\text {eq }}$ varied from 3.30 to 18.12 
Table 2. The activities in Bq. $\mathrm{kg}^{-1}$ of ${ }^{40} \mathrm{~K},{ }^{226} \mathrm{Ra}$ and ${ }^{232} \mathrm{Th}$ of the samples investigated in comparison with other countries.

\begin{tabular}{|c|c|c|c|c|c|}
\hline \multirow{2}{*}{ Country } & \multicolumn{3}{|c|}{ Activity concentration $\left(\mathrm{Bq} \cdot \mathrm{kg}^{-1}\right)$} & \multirow{2}{*}{$\begin{array}{c}R a_{e q} \\
\left(\mathrm{~Bq} \cdot \mathrm{kg}^{-1}\right)\end{array}$} & \multirow{2}{*}{ Reference } \\
\hline & ${ }^{226} \mathrm{Ra}$ & ${ }^{232} \mathrm{Th}$ & ${ }^{40} \mathrm{~K}$ & & \\
\hline Kenya, Kargi & 7 & 8 & 355 & 46 & Present work \\
\hline Iraq, Destroyed fuel facility & 16 & 14 & 306 & 60 & Abdulla et al., 2016 \\
\hline India, Tamilnadu & 116 & 44 & 300 & 201 & Raghu et al., 2017 \\
\hline Nigeria, Port Harcourt & 5 & 4 & 16 & 11 & Avwiri et al., 2013 \\
\hline Kenya, Sakwa Wagusu & 44 & 40 & 640 & 141 & Aguko et al., 2013 \\
\hline Turkey, Kirklareli & 37 & 40 & 667 & - & Taskin et al., 2009 \\
\hline World average & 37 & 33 & 400 & 370 & $\begin{array}{l}\text { UNSCEAR, 2008; } \\
\text { Lu \& Zhang, } 2006\end{array}$ \\
\hline
\end{tabular}

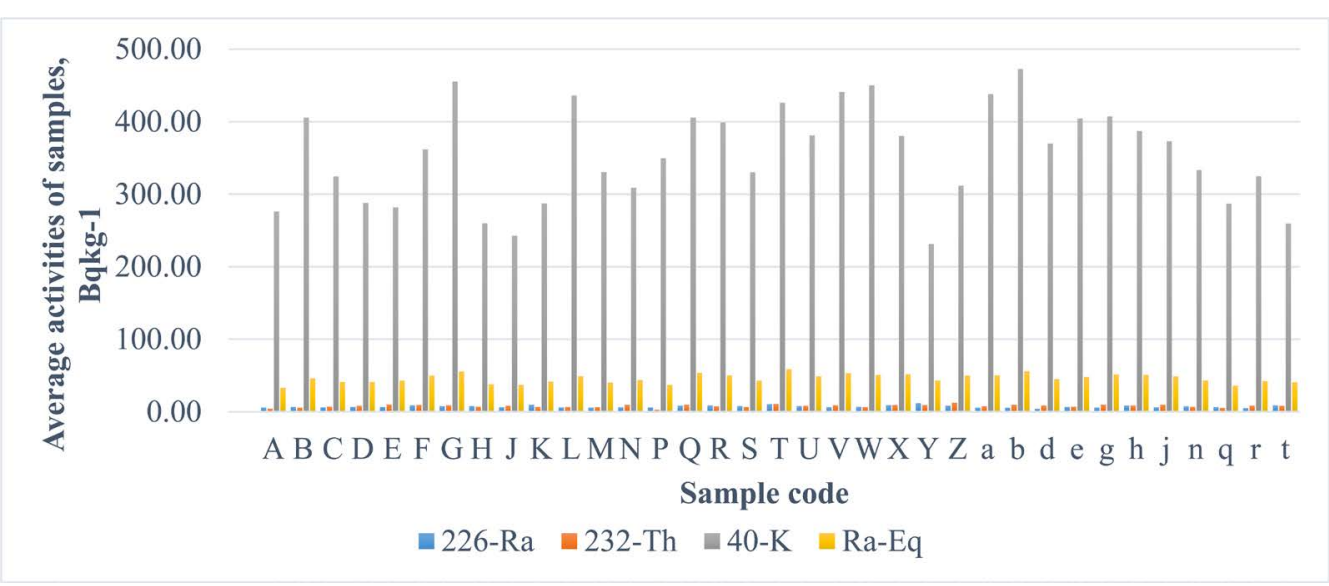

Figure 3. Activity values of samples due to ${ }^{226} \mathrm{Ra},{ }^{232} \mathrm{Th},{ }^{40} \mathrm{~K}$ together with $R a_{e q}$ in Kargi.

$\mathrm{Bq} \cdot \mathrm{kg}^{-1}, 0.00$ to $17.80 \mathrm{~Bq} \cdot \mathrm{kg}^{-1}, 36.87$ to $667.77 \mathrm{~Bq} \cdot \mathrm{kg}^{-1}$, and 18.09 to 102.34 $\mathrm{Bq} \cdot \mathrm{kg}^{-1}$ with arithmetic mean and standard deviation as $7.40 \pm 2.61,7.98 \pm 4.01$, $351.74 \pm 109.63$ and $45.90 \pm 12.65$ respectively. This is seen from Table 1. Globally, recommended values are respectively $37.0 \mathrm{~Bq} \cdot \mathrm{kg}^{-1}, 33.0 \mathrm{~Bq} \cdot \mathrm{kg}^{-1}, 400.0$ $\mathrm{Bq} \cdot \mathrm{kg}^{-1}$ (UNSCEAR, 2008) and $370 \mathrm{~Bq} \cdot \mathrm{kg}^{-1}$ (Lu \& Zhang, 2006). Figure 3 gives a more illustrative level of the activities.

All mean activities for ${ }^{226} \mathrm{Ra},{ }^{232} \mathrm{Th},{ }^{40} \mathrm{~K}$ together with $R a_{e q}$ were less than the global values recommendation.

Mean calculated absorbed dose rates for all soil samples was $23.87 \pm 3.48$ $\mathrm{nGy} \cdot \mathrm{h}^{-1}$ against the global median value of $54 \mathrm{nGy} \cdot \mathrm{h}^{-1}$ (UNSCEAR, 2000). The values varied between $16.06 \pm 1.09$ and $29.35 \pm 1.32 \mathrm{nGy} \cdot \mathrm{h}^{-1}$, figures which are less than the required value (Table 4). The $A E D E(D e)$ values were found lower than the global value of $1 \mathrm{mSv} \cdot \mathrm{y}^{-1}$ (ICRP, 2000) with a mean and standard deviation value of $0.14 \pm 0.03 \mathrm{mSv} \cdot \mathrm{y}^{-1}$, varying from $0.11 \pm 0.01$ to $0.18 \pm 0.06$ $\mathrm{mSv} \cdot \mathrm{y}^{-1}$.

Excess lifetime cancer risk is an added risk that one might have on contracting cancer disease if susceptible for longer time to cancer disease causing materials. 
Taking 70 years as mean life duration with a risk factor of 0.05 per Sv (ICRP, 2007; Taskin et al., 2009) and a median annual effective dose rate of 0.14 $\mathrm{mSv} \cdot \mathrm{y}^{-1}$, then excess cancer risk is computed as $0.05 \%$. This value is less than world agreed value of 0.145\% (Taskin et al., 2009; UNSCEAR, 2000). Table 4 tabulates the above values.

Elemental radionuclide concentrations in the samples were calculated from the activity concentrations in $\mathrm{Bq} \cdot \mathrm{kg}^{-1}$ by use of conversion factors in Equations (13)-(15). These results are presented in Table 5. From the table, the calculated elemental concentrations ranged from $0.74 \%$ to $1.51 \%, 0.68$ to $3.04 \mathrm{ppm}$ and 0.33 to $0.97 \mathrm{ppm}$ for potassium, uranium and thorium respectively with respective arithmetic mean and standard deviation of $1.13 \% \pm 0.21 \%, 1.98 \pm 0.47 \mathrm{ppm}$, $0.59 \pm 0.13 \mathrm{ppm}$.

Tzortzis \& Tsertos (2004) and Al-Hamarneh \& Awadalla (2009) noted that a high or low value of Th/U ratios as measured in some studied locations may be an indication of a uranium depletion or thorium enrichment due to natural processes alteration in that area. They approximated the theoretical normal continental crust values of $\mathrm{Th} / \mathrm{U}$ elemental ratios to be 3.0. From Table 5, our $\mathrm{Th} / \mathrm{U}$ results ranged from $1.19 \pm 0.85$ to $6.35 \pm 1.72$ with mean and standard deviation of $3.57 \pm 1.13$. Other correlation ratios of $\mathrm{K} / \mathrm{U}$ together with $\mathrm{K} / \mathrm{Th}$ varied from $0.84 \pm 0.46$ to $3.89 \pm 2.13$ together with $0.34 \pm 0.09$ to 1.94 \pm 2.42 with mean and standard deviations of $2.15 \pm 0.67$ and $0.68 \pm 0.30$ respectively.

Correlations existing between activities ${ }^{232} \mathrm{Th}$ and ${ }^{238} \mathrm{U},{ }^{40} \mathrm{~K}$ and ${ }^{238} \mathrm{U}$ together with ${ }^{40} \mathrm{~K}$ and ${ }^{232} \mathrm{Th}$ showed a weak relationship existing on ${ }^{232} \mathrm{Th}$ against ${ }^{238} \mathrm{U},{ }^{40} \mathrm{~K}$ against ${ }^{238} \mathrm{U}$ together with ${ }^{40} \mathrm{~K}$ against ${ }^{232} \mathrm{Th}$ with correlation coefficients of 0.405 , 0.134 and 0.319 respectively.

Respective mean values together with their standard deviations of representative alpha $\left(I_{\alpha}\right)$, representative gamma $\left(I_{\gamma}\right)$, internal hazard $\left(H_{i n}\right)$, external hazard $\left(H_{e x}\right)$ indices and Annual Gonadal Equivalent Dose $(A G E D)$ values, as seen from Table 3 are $167.32 \pm 23.56,0.12 \pm 0.02,0.14 \pm 0.02,0.18 \pm 0.03$ and $0.03 \pm 0.01 \mathrm{mSv} \cdot \mathrm{y}^{-1}$ with ranges from $122.70 \pm 13.39$ to $210.84 \pm 62.88,0.09 \pm$ 0.01 to $0.16 \pm 0.05,0.11 \pm 0.01$ to $0.17 \pm 0.05,0.13 \pm 0.01$ to $0.23 \pm 0.07$ and $0.02 \pm 0.01$ to $0.05 \pm 0.02 \mathrm{mSv} \cdot \mathrm{y}^{-1}$. A pictorial representation of hazard indices is shown in Figure 4.

\section{Conclusion}

Results from the study give the mean activities for the area as $354.81 \pm 67.06$, $7.23 \pm 1.67$ and $8.03 \pm 1.91 \mathrm{~Bq} \cdot \mathrm{kg}^{-1}$ against the world standard values of 400, 35 and $30 \mathrm{~Bq} \cdot \mathrm{kg}^{-1}$ for ${ }^{40} \mathrm{~K},{ }^{226} \mathrm{Ra}$ together with ${ }^{232} \mathrm{Th}$ (UNSCEAR, 2000) respectively. The area generally cannot be classified as a High Background Radiation Area (HBRA), thus good for human settlement.

Mean evaluated absorbed dose rate was below recommended values by almost half. Annual effective dose rate values were found lower than global value of 1 
Table 3. Calculated values of representative alpha $\left(I_{\alpha}\right)$, representative gamma $\left(I_{\gamma}\right)$, internal hazard $\left(H_{\text {in }}\right)$, external hazard $\left(H_{e x}\right)$ indices and Annual Gonadal Equivalent Dose $(A G E D)$.

\begin{tabular}{|c|c|c|c|c|c|}
\hline $\begin{array}{l}\text { Sample area } \\
\text { code }\end{array}$ & $\begin{array}{l}A G E D \\
\left(\mathrm{~Sv} \cdot \mathrm{y}^{-1}\right)\end{array}$ & $\begin{array}{l}\text { External hazard } \\
\text { index }\left(H_{e x}\right)\end{array}$ & $\begin{array}{l}\text { Internal hazard } \\
\text { index }\left(H_{i n}\right)\end{array}$ & $\begin{array}{c}\text { Representative } \\
\text { gamma index }\left(I_{\gamma}\right)\end{array}$ & $\begin{array}{l}\text { Representative } \\
\text { alpha index }\left(I_{\alpha}\right)\end{array}$ \\
\hline A & $122.70 \pm 13.39$ & $0.09 \pm 0.01$ & $0.11 \pm 0.01$ & $0.13 \pm 0.01$ & $0.03 \pm 0.01$ \\
\hline B & $171.76 \pm 21.89$ & $0.12 \pm 0.01$ & $0.14 \pm 0.02$ & $0.19 \pm 0.02$ & $0.03 \pm 0.01$ \\
\hline $\mathrm{C}$ & $150.02 \pm 19.38$ & $0.11 \pm 0.01$ & $0.13 \pm 0.02$ & $0.16 \pm 0.02$ & $0.03 \pm 0.01$ \\
\hline $\mathrm{D}$ & $146.71 \pm 29.63$ & $0.11 \pm 0.02$ & $0.13 \pm 0.02$ & $0.16 \pm 0.03$ & $0.03 \pm 0.01$ \\
\hline $\mathrm{E}$ & $151.40 \pm 53.02$ & $0.12 \pm 0.04$ & $0.13 \pm 0.05$ & $0.17 \pm 0.06$ & $0.03 \pm 0.02$ \\
\hline F & $180.02 \pm 64.35$ & $0.14 \pm 0.05$ & $0.16 \pm 0.05$ & $0.20 \pm 0.07$ & $0.04 \pm 0.01$ \\
\hline G & $204.42 \pm 29.93$ & $0.15 \pm 0.02$ & $0.17 \pm 0.02$ & $0.22 \pm 0.03$ & $0.04 \pm 0.01$ \\
\hline $\mathrm{H}$ & $135.11 \pm 22.23$ & $0.10 \pm 0.02$ & $0.12 \pm 0.02$ & $0.15 \pm 0.03$ & $0.04 \pm 0.01$ \\
\hline $\mathrm{J}$ & $130.86 \pm 30.13$ & $0.10 \pm 0.02$ & $0.12 \pm 0.02$ & $0.14 \pm 0.03$ & $0.03 \pm 0.01$ \\
\hline K & $148.85 \pm 48.37$ & $0.11 \pm 0.04$ & $0.14 \pm 0.05$ & $0.16 \pm 0.05$ & $0.05 \pm 0.03$ \\
\hline $\mathrm{L}$ & $182.89 \pm 21.25$ & $0.13 \pm 0.02$ & $0.15 \pm 0.02$ & $0.20 \pm 0.02$ & $0.03 \pm 0.00$ \\
\hline M & $147.99 \pm 6.13$ & $0.11 \pm 0.00$ & $0.12 \pm 0.01$ & $0.16 \pm 0.01$ & $0.03 \pm 0.01$ \\
\hline $\mathrm{N}$ & $156.40 \pm 59.19$ & $0.12 \pm 0.05$ & $0.13 \pm 0.05$ & $0.17 \pm 0.07$ & $0.03 \pm 0.00$ \\
\hline $\mathrm{P}$ & $139.97 \pm 10.12$ & $0.10 \pm 0.01$ & $0.12 \pm 0.01$ & $0.15 \pm 0.01$ & $0.03 \pm 0.01$ \\
\hline Q & $194.17 \pm 64.19$ & $0.14 \pm 0.05$ & $0.17 \pm 0.05$ & $0.21 \pm 0.07$ & $0.04 \pm 0.01$ \\
\hline $\mathrm{R}$ & $183.43 \pm 21.01$ & $0.14 \pm 0.02$ & $0.16 \pm 0.02$ & $0.20 \pm 0.02$ & $0.04 \pm 0.01$ \\
\hline S & $156.20 \pm 15.13$ & $0.12 \pm 0.01$ & $0.14 \pm 0.01$ & $0.17 \pm 0.02$ & $0.04 \pm 0.00$ \\
\hline $\mathrm{T}$ & $210.84 \pm 62.88$ & $0.16 \pm 0.05$ & $0.19 \pm 0.06$ & $0.23 \pm 0.07$ & $0.05 \pm 0.02$ \\
\hline $\mathrm{U}$ & $178.32 \pm 64.35$ & $0.13 \pm 0.05$ & $0.15 \pm 0.05$ & $0.19 \pm 0.07$ & $0.04 \pm 0.01$ \\
\hline $\mathrm{V}$ & $195.54 \pm 110.31$ & $0.14 \pm 0.09$ & $0.16 \pm 0.10$ & $0.21 \pm 0.12$ & $0.03 \pm 0.02$ \\
\hline $\mathrm{W}$ & $189.85 \pm 31.53$ & $0.14 \pm 0.03$ & $0.16 \pm 0.03$ & $0.21 \pm 0.04$ & $0.03 \pm 0.01$ \\
\hline $\mathrm{X}$ & $186.35 \pm 106.41$ & $0.14 \pm 0.08$ & $0.16 \pm 0.09$ & $0.20 \pm 0.12$ & $0.05 \pm 0.02$ \\
\hline $\mathrm{Y}$ & $148.45 \pm 39.66$ & $0.12 \pm 0.03$ & $0.15 \pm 0.02$ & $0.16 \pm 0.04$ & $0.06 \pm 0.01$ \\
\hline $\mathrm{Z}$ & $175.79 \pm 17.49$ & $0.14 \pm 0.02$ & $0.16 \pm 0.02$ & $0.19 \pm 0.02$ & $0.04 \pm 0.01$ \\
\hline $\mathrm{a}$ & $187.03 \pm 43.74$ & $0.14 \pm 0.03$ & $0.15 \pm 0.02$ & $0.20 \pm 0.05$ & $0.03 \pm 0.01$ \\
\hline $\mathrm{b}$ & $206.20 \pm 5.84$ & $0.15 \pm 0.01$ & $0.17 \pm 0.01$ & $0.22 \pm 0.01$ & $0.03 \pm 0.00$ \\
\hline $\mathrm{d}$ & $165.08 \pm 14.28$ & $0.12 \pm 0.00$ & $0.13 \pm 0.00$ & $0.18 \pm 0.01$ & $0.02 \pm 0.01$ \\
\hline e & $177.05 \pm 31.75$ & $0.13 \pm 0.02$ & $0.15 \pm 0.03$ & $0.19 \pm 0.03$ & $0.03 \pm 0.01$ \\
\hline g & $186.95 \pm 0.00$ & $0.14 \pm 0.00$ & $0.15 \pm 0.00$ & $0.20 \pm 0.00$ & $0.03 \pm 0.00$ \\
\hline $\mathrm{h}$ & $184.24 \pm 24.06$ & $0.14 \pm 0.02$ & $0.16 \pm 0.03$ & $0.20 \pm 0.03$ & $0.04 \pm 0.01$ \\
\hline j & $177.10 \pm 3.64$ & $0.13 \pm 0.00$ & $0.15 \pm 0.01$ & $0.19 \pm 0.00$ & $0.03 \pm 0.01$ \\
\hline $\mathrm{n}$ & $156.86 \pm 7.55$ & $0.12 \pm 0.00$ & $0.14 \pm 0.00$ & $0.17 \pm 0.01$ & $0.04 \pm 0.00$ \\
\hline $\mathrm{q}$ & $131.67 \pm 14.49$ & $0.10 \pm 0.01$ & $0.11 \pm 0.02$ & $0.14 \pm 0.02$ & $0.02 \pm 0.03$ \\
\hline $\mathrm{r}$ & $152.92 \pm 5.20$ & $0.11 \pm 0.00$ & $0.13 \pm 0.00$ & $0.17 \pm 0.01$ & $0.02 \pm 0.01$ \\
\hline $\mathrm{t}$ & $143.17 \pm 44.34$ & $0.11 \pm 0.03$ & $0.13 \pm 0.03$ & $0.16 \pm 0.05$ & $0.04 \pm 0.01$ \\
\hline Average & $167.32 \pm 23.56$ & $0.12 \pm 0.02$ & $0.14 \pm 0.02$ & $0.18 \pm 0.03$ & $0.03 \pm 0.01$ \\
\hline
\end{tabular}


Table 4. Gamma dose rates, $A E D E(D e)$ and excess lifetime cancer risk (ELCR) as per sources.

\begin{tabular}{|c|c|c|c|c|c|}
\hline \multirow{2}{*}{$\begin{array}{l}\text { Sample area } \\
\text { code }\end{array}$} & \multirow{2}{*}{$\begin{array}{l}\text { Absorbed gamma dose } \\
\text { rate, } D, \mathrm{nGy} \cdot \mathrm{h}^{-1}\end{array}$} & \multicolumn{3}{|c|}{ Annual effective dose rate, $D e, \mathrm{mSv} \cdot \mathrm{y}^{-1}$} & \multirow{2}{*}{$\begin{array}{c}\text { Excess Lifetime } \\
\text { Cancer Risk }(E L C R) \\
\text { Adults }\end{array}$} \\
\hline & & Out & In & Total & \\
\hline A & $17.44 \pm 1.85$ & $0.04 \pm 0.01$ & $0.06 \pm 0.01$ & $0.11 \pm 0.01$ & $0.37 \pm 0.04$ \\
\hline B & $24.32 \pm 3.01$ & $0.06 \pm 0.01$ & $0.09 \pm 0.01$ & $0.15 \pm 0.02$ & $0.52 \pm 0.06$ \\
\hline $\mathrm{C}$ & $21.44 \pm 2.63$ & $0.05 \pm 0.01$ & $0.08 \pm 0.01$ & $0.13 \pm 0.02$ & $0.46 \pm 0.06$ \\
\hline $\mathrm{D}$ & $21.14 \pm 4.22$ & $0.05 \pm 0.01$ & $0.08 \pm 0.02$ & $0.13 \pm 0.03$ & $0.45 \pm 0.09$ \\
\hline $\mathrm{E}$ & $21.93 \pm 7.58$ & $0.05 \pm 0.02$ & $0.08 \pm 0.03$ & $0.13 \pm 0.05$ & $0.47 \pm 0.16$ \\
\hline $\mathrm{F}$ & $25.88 \pm 9.37$ & $0.06 \pm 0.02$ & $0.10 \pm 0.03$ & $0.16 \pm 0.06$ & $0.56 \pm 0.20$ \\
\hline G & $29.14 \pm 4.09$ & $0.07 \pm 0.01$ & $0.11 \pm 0.02$ & $0.18 \pm 0.03$ & $0.63 \pm 0.09$ \\
\hline $\mathrm{H}$ & $19.47 \pm 3.29$ & $0.05 \pm 0.01$ & $0.07 \pm 0.01$ & $0.12 \pm 0.02$ & $0.42 \pm 0.07$ \\
\hline $\mathrm{J}$ & $18.95 \pm 4.17$ & $0.05 \pm 0.01$ & $0.07 \pm 0.02$ & $0.12 \pm 0.03$ & $0.41 \pm 0.09$ \\
\hline $\mathrm{K}$ & $21.42 \pm 6.92$ & $0.05 \pm 0.02$ & $0.08 \pm 0.03$ & $0.13 \pm 0.04$ & $0.46 \pm 0.15$ \\
\hline $\mathrm{L}$ & $25.90 \pm 3.11$ & $0.06 \pm 0.01$ & $0.10 \pm 0.01$ & $0.16 \pm 0.02$ & $0.56 \pm 0.07$ \\
\hline M & $21.09 \pm 0.74$ & $0.05 \pm 0.00$ & $0.08 \pm 0.00$ & $0.13 \pm 0.01$ & $0.45 \pm 0.02$ \\
\hline $\mathrm{N}$ & $22.56 \pm 8.60$ & $0.06 \pm 0.02$ & $0.08 \pm 0.03$ & $0.14 \pm 0.05$ & $0.48 \pm 0.18$ \\
\hline $\mathrm{P}$ & $19.68 \pm 1.37$ & $0.05 \pm 0.00$ & $0.07 \pm 0.01$ & $0.12 \pm 0.01$ & $0.42 \pm 0.03$ \\
\hline $\mathrm{Q}$ & $27.83 \pm 9.11$ & $0.07 \pm 0.02$ & $0.10 \pm 0.03$ & $0.17 \pm 0.06$ & $0.60 \pm 0.20$ \\
\hline $\mathrm{R}$ & $26.17 \pm 3.13$ & $0.06 \pm 0.01$ & $0.10 \pm 0.01$ & $0.16 \pm 0.02$ & $0.56 \pm 0.07$ \\
\hline S & $22.34 \pm 2.10$ & $0.05 \pm 0.01$ & $0.08 \pm 0.01$ & $0.13 \pm 0.01$ & $0.48 \pm 0.05$ \\
\hline $\mathrm{T}$ & $30.29 \pm 9.15$ & $0.07 \pm 0.02$ & $0.11 \pm 0.03$ & $0.18 \pm 0.06$ & $0.65 \pm 0.20$ \\
\hline $\mathrm{U}$ & $25.40 \pm 9.07$ & $0.06 \pm 0.02$ & $0.09 \pm 0.03$ & $0.15 \pm 0.06$ & $0.55 \pm 0.19$ \\
\hline $\mathrm{V}$ & $27.86 \pm 16.38$ & $0.07 \pm 0.04$ & $0.10 \pm 0.06$ & $0.17 \pm 0.10$ & $0.60 \pm 0.35$ \\
\hline $\mathrm{W}$ & $26.89 \pm 4.71$ & $0.07 \pm 0.01$ & $0.10 \pm 0.02$ & $0.17 \pm 0.03$ & $0.58 \pm 0.10$ \\
\hline $\mathrm{X}$ & $26.75 \pm 15.19$ & $0.07 \pm 0.04$ & $0.10 \pm 0.06$ & $0.17 \pm 0.09$ & $0.57 \pm 0.33$ \\
\hline $\mathrm{Y}$ & $21.69 \pm 5.77$ & $0.05 \pm 0.01$ & $0.08 \pm 0.02$ & $0.13 \pm 0.04$ & $0.47 \pm 0.12$ \\
\hline Z & $25.55 \pm 2.67$ & $0.06 \pm 0.01$ & $0.09 \pm 0.01$ & $0.15 \pm 0.02$ & $0.55 \pm 0.06$ \\
\hline a & $26.55 \pm 6.00$ & $0.07 \pm 0.01$ & $0.10 \pm 0.02$ & $0.17 \pm 0.04$ & $0.57 \pm 0.13$ \\
\hline $\mathrm{b}$ & $29.35 \pm 1.32$ & $0.07 \pm 0.00$ & $0.11 \pm 0.00$ & $0.18 \pm 0.01$ & $0.63 \pm 0.03$ \\
\hline $\mathrm{d}$ & $23.61 \pm 1.49$ & $0.06 \pm 0.00$ & $0.09 \pm 0.01$ & $0.15 \pm 0.01$ & $0.51 \pm 0.03$ \\
\hline e & $25.17 \pm 4.43$ & $0.06 \pm 0.01$ & $0.09 \pm 0.02$ & $0.15 \pm 0.03$ & $0.54 \pm 0.10$ \\
\hline g & $26.74 \pm 0.00$ & $0.07 \pm 0.00$ & $0.10 \pm 0.00$ & $0.17 \pm 0.00$ & $0.57 \pm 0.00$ \\
\hline $\mathrm{h}$ & $26.38 \pm 3.47$ & $0.06 \pm 0.01$ & $0.10 \pm 0.01$ & $0.16 \pm 0.02$ & $0.57 \pm 0.07$ \\
\hline j & $25.40 \pm 0.41$ & $0.01 \pm 0.00$ & $0.01 \pm 0.00$ & $0.02 \pm 0.01$ & $0.06 \pm 0.02$ \\
\hline $\mathrm{n}$ & $22.43 \pm 0.98$ & $0.06 \pm 0.00$ & $0.08 \pm 0.00$ & $0.14 \pm 0.01$ & $0.48 \pm 0.02$ \\
\hline $\mathrm{q}$ & $16.06 \pm 1.09$ & $0.04 \pm 0.00$ & $0.06 \pm 0.00$ & $0.10 \pm 0.01$ & $0.34 \pm 0.02$ \\
\hline $\mathrm{r}$ & $21.92 \pm 0.78$ & $0.05 \pm 0.00$ & $0.08 \pm 0.00$ & $0.13 \pm 0.00$ & $0.47 \pm 0.02$ \\
\hline $\mathrm{t}$ & $20.73 \pm 6.19$ & $0.05 \pm 0.02$ & $0.08 \pm 0.02$ & $0.13 \pm 0.04$ & $0.44 \pm 0.13$ \\
\hline Average & $23.87 \pm 3.48$ & $0.06 \pm 0.01$ & $0.09 \pm 0.02$ & $0.14 \pm 0.03$ & $0.50 \pm 0.11$ \\
\hline
\end{tabular}


Table 5. Elemental concentration of specific activity of ${ }^{40} \mathrm{~K},{ }^{238} \mathrm{U}$ together with ${ }^{232} \mathrm{Th}(\mathrm{ppm})$ in samples with their ratios.

\begin{tabular}{|c|c|c|c|c|c|c|}
\hline Sample area code & ${ }^{238} \mathrm{U}$ & ${ }^{232} \mathrm{Th}$ & ${ }^{40} \mathrm{~K}$ & $\mathrm{Th} / \mathrm{U}$ & $\mathrm{K} / \mathrm{U}$ & $\mathrm{K} / \mathrm{Th}$ \\
\hline A & $0.47 \pm 0.16$ & $1.06 \pm 0.50$ & $0.88 \pm 0.15$ & $2.64 \pm 1.76$ & $2.06 \pm 0.89$ & $1.06 \pm 0.67$ \\
\hline B & $0.55 \pm 0.18$ & $1.39 \pm 0.46$ & $1.30 \pm 0.27$ & $2.52 \pm 0.29$ & $2.62 \pm 1.08$ & $1.04 \pm 0.44$ \\
\hline $\mathrm{C}$ & $0.49 \pm 0.10$ & $1.73 \pm 0.56$ & $1.04 \pm 0.22$ & $3.67 \pm 1.71$ & $2.13 \pm 0.43$ & $0.68 \pm 0.35$ \\
\hline $\mathrm{D}$ & $0.55 \pm 0.13$ & $2.07 \pm 0.55$ & $0.92 \pm 0.24$ & $3.84 \pm 0.96$ & $1.78 \pm 0.77$ & $0.45 \pm 0.14$ \\
\hline $\mathrm{E}$ & $0.55 \pm 0.24$ & $2.48 \pm 1.06$ & $0.90 \pm 0.38$ & $5.06 \pm 2.26$ & $1.68 \pm 0.46$ & $0.40 \pm 0.21$ \\
\hline $\mathrm{F}$ & $0.72 \pm 0.13$ & $2.30 \pm 1.36$ & $1.16 \pm 0.38$ & $3.06 \pm 1.23$ & $1.58 \pm 0.21$ & $0.57 \pm 0.20$ \\
\hline G & $0.63 \pm 0.12$ & $2.21 \pm 0.79$ & $1.45 \pm 0.32$ & $3.74 \pm 1.97$ & $2.32 \pm 0.37$ & $0.75 \pm 0.35$ \\
\hline $\mathrm{H}$ & $0.64 \pm 0.11$ & $1.72 \pm 0.90$ & $0.83 \pm 0.17$ & $2.69 \pm 1.42$ & $1.35 \pm 0.47$ & $0.65 \pm 0.45$ \\
\hline $\mathrm{J}$ & $0.51 \pm 0.15$ & $2.08 \pm 0.08$ & $0.77 \pm 0.29$ & $4.33 \pm 1.24$ & $1.61 \pm 0.74$ & $0.37 \pm 0.13$ \\
\hline $\mathrm{K}$ & $0.79 \pm 0.45$ & $1.68 \pm 0.28$ & $0.92 \pm 0.32$ & $2.46 \pm 0.79$ & $1.29 \pm 0.46$ & $0.54 \pm 0.12$ \\
\hline $\mathrm{L}$ & $0.48 \pm 0.06$ & $1.63 \pm 0.64$ & $1.39 \pm 0.13$ & $3.53 \pm 1.64$ & $2.94 \pm 0.51$ & $0.98 \pm 0.44$ \\
\hline M & $0.46 \pm 0.11$ & $1.57 \pm 0.19$ & $1.06 \pm 0.08$ & $3.50 \pm 0.77$ & $2.38 \pm 0.56$ & $0.69 \pm 0.15$ \\
\hline $\mathrm{N}$ & $0.50 \pm 0.06$ & $2.39 \pm 1.35$ & $0.99 \pm 0.37$ & $4.71 \pm 2.28$ & $1.99 \pm 0.67$ & $0.45 \pm 0.13$ \\
\hline $\mathrm{P}$ & $0.49 \pm 0.19$ & $0.68 \pm 0.64$ & $1.12 \pm 0.23$ & $1.19 \pm 0.85$ & $2.60 \pm 1.12$ & $1.24 \pm 1.23$ \\
\hline Q & $0.69 \pm 0.22$ & $2.39 \pm 0.91$ & $1.30 \pm 0.50$ & $3.57 \pm 0.98$ & $1.88 \pm 0.33$ & $0.58 \pm 0.30$ \\
\hline $\mathrm{R}$ & $0.71 \pm 0.18$ & $1.84 \pm 0.69$ & $1.27 \pm 0.11$ & $2.67 \pm 0.90$ & $1.87 \pm 0.35$ & $0.77 \pm 0.30$ \\
\hline S & $0.64 \pm 0.02$ & $1.65 \pm 0.40$ & $1.05 \pm 0.16$ & $2.57 \pm 0.58$ & $1.64 \pm 0.25$ & $0.67 \pm 0.18$ \\
\hline $\mathrm{T}$ & $0.85 \pm 0.28$ & $2.62 \pm 1.45$ & $1.36 \pm 0.42$ & $2.92 \pm 1.11$ & $1.68 \pm 0.56$ & $0.64 \pm 0.32$ \\
\hline $\mathrm{U}$ & $0.63 \pm 0.14$ & $2.05 \pm 0.79$ & $1.22 \pm 0.54$ & $3.31 \pm 1.23$ & $1.98 \pm 0.82$ & $0.62 \pm 0.30$ \\
\hline V & $0.51 \pm 0.29$ & $2.21 \pm 3.08$ & $1.41 \pm 0.48$ & $3.08 \pm 2.98$ & $2.99 \pm 0.73$ & $0.68 \pm 0.66$ \\
\hline $\mathrm{W}$ & $0.55 \pm 0.11$ & $1.61 \pm 1.05$ & $1.44 \pm 0.17$ & $2.68 \pm 1.53$ & $2.67 \pm 0.61$ & $1.94 \pm 2.42$ \\
\hline $\mathrm{X}$ & $0.73 \pm 0.38$ & $2.30 \pm 1.47$ & $1.21 \pm 0.79$ & $3.03 \pm 0.52$ & $2.00 \pm 1.72$ & $0.64 \pm 0.57$ \\
\hline $\mathrm{Y}$ & $0.97 \pm 0.23$ & $2.29 \pm 1.26$ & $0.74 \pm 0.23$ & $2.65 \pm 1.67$ & $0.84 \pm 0.46$ & $0.40 \pm 0.20$ \\
\hline $\mathrm{Z}$ & $0.69 \pm 0.17$ & $3.04 \pm 0.77$ & $1.00 \pm 0.11$ & $4.56 \pm 1.40$ & $1.52 \pm 0.47$ & $0.34 \pm 0.09$ \\
\hline $\mathrm{a}$ & $0.45 \pm 0.13$ & $1.90 \pm 0.21$ & $1.40 \pm 0.46$ & $4.42 \pm 1.73$ & $3.37 \pm 1.98$ & $0.73 \pm 0.16$ \\
\hline $\mathrm{b}$ & $0.45 \pm 0.03$ & $2.40 \pm 1.47$ & $1.51 \pm 0.18$ & $5.46 \pm 3.59$ & $3.36 \pm 0.22$ & $0.80 \pm 0.57$ \\
\hline $\mathrm{d}$ & $0.33 \pm 0.08$ & $2.15 \pm 1.10$ & $1.18 \pm 0.37$ & $6.35 \pm 1.72$ & $3.89 \pm 2.13$ & $0.68 \pm 0.52$ \\
\hline e & $0.55 \pm 0.14$ & $1.72 \pm 0.02$ & $1.29 \pm 0.26$ & $3.24 \pm 0.82$ & $2.37 \pm 0.14$ & $0.75 \pm 0.15$ \\
\hline g & $0.47 \pm 0.00$ & $2.44 \pm 0.00$ & $1.30 \pm 0.00$ & $5.23 \pm 0.00$ & $2.79 \pm 0.00$ & $0.53 \pm 0.00$ \\
\hline $\mathrm{h}$ & $0.69 \pm 0.21$ & $2.13 \pm 0.16$ & $1.24 \pm 0.14$ & $3.17 \pm 0.72$ & $1.83 \pm 0.35$ & $0.58 \pm 0.02$ \\
\hline j & $0.50 \pm 0.18$ & $2.42 \pm 0.03$ & $1.19 \pm 0.10$ & $5.27 \pm 2.02$ & $2.63 \pm 1.18$ & $0.49 \pm 0.04$ \\
\hline $\mathrm{n}$ & $0.62 \pm 0.01$ & $1.69 \pm 0.17$ & $1.06 \pm 0.10$ & $2.75 \pm 0.31$ & $1.73 \pm 0.15$ & $0.64 \pm 0.13$ \\
\hline$q$ & $0.52 \pm 0.21$ & $1.27 \pm 0.18$ & $0.92 \pm 0.04$ & $2.57 \pm 0.68$ & $1.88 \pm 0.67$ & $0.72 \pm 0.07$ \\
\hline $\mathrm{r}$ & $0.40 \pm 0.10$ & $2.10 \pm 0.33$ & $1.04 \pm 0.03$ & $5.53 \pm 2.18$ & $2.69 \pm 0.74$ & $0.50 \pm 0.06$ \\
\hline $\mathrm{t}$ & $0.71 \pm 0.12$ & $2.04 \pm 0.51$ & $0.83 \pm 0.41$ & $2.97 \pm 1.22$ & $1.23 \pm 0.79$ & $0.39 \pm 0.10$ \\
\hline Average & $0.59 \pm 0.13$ & $1.98 \pm 0.47$ & $1.13 \pm 0.21$ & $3.57 \pm 1.13$ & $2.15 \pm 0.67$ & $0.68 \pm 0.30$ \\
\hline
\end{tabular}




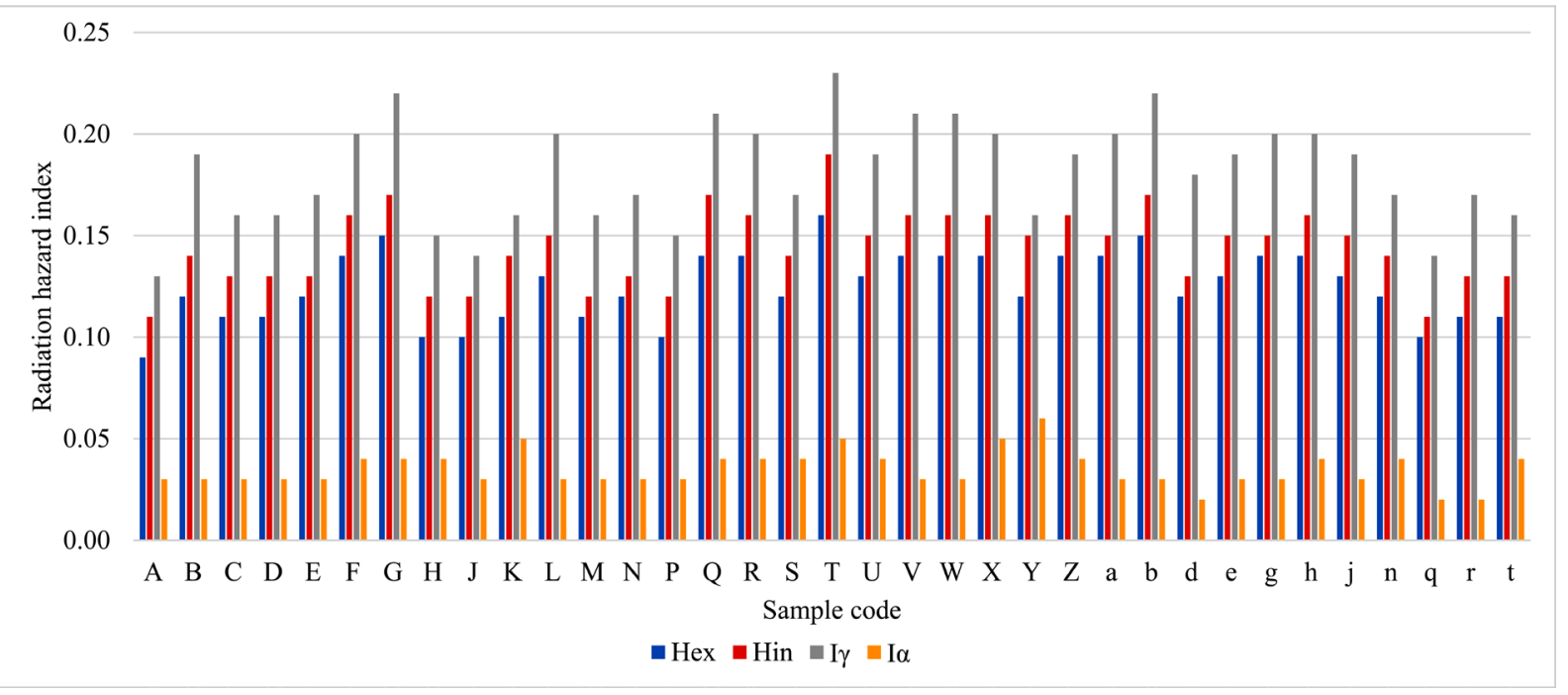

Figure 4. Hazard indices values for entire Kargi area.

$\mathrm{mSv} \cdot \mathrm{y}^{-1}$, which, for the public exposure is the annual effective dose rate limit (ICRP, 2000).

Hazard indices $\left(H_{i n}, H_{e x}, I_{\gamma}\right.$ and $\left.I_{\alpha}\right)$ together with Radium equivalent $\left(R a_{e q}\right)$ values for the studied area were lower than values recommended of $1\left(H_{i n}, H_{e x}\right.$ and $I_{\gamma}$ ), $0.5\left(I_{a}\right)$ and $370 \mathrm{~Bq} \cdot \mathrm{kg}^{-1}$ (Lu \& Zhang, 2006). Radiation risk associated with these soils can be considered negligible making the rocks and soils in the area safe for construction causing no important radiological threat to populace.

Excess cancer risk, calculated from the samples showed lower values hence minimal chance of getting cancer disease. The area is safe from cancer causing radionuclides.

Because Th/U value was higher than the recommended, the study can therefore conclude that there could have been a fractionation during weathering or involvement of metasomatic activity of the radioelements.

\section{Acknowledgements}

The authors thank Jomo Kenyatta University of Agriculture \& Technology (JKUAT), Kenya Bureau of Standards (KEBS) for their mass measurements and oven drying facility, University of Nairobi's Nuclear Science and Technology Institute (INST) for laboratory analysis and $\gamma$-ray spectrometer, Kargi administration, my family and Research assistant, Lydia Okemwa of Technical University of Kenya, TUK.

\section{Conflicts of Interest}

The authors declare no conflicts of interest regarding the publication of this paper.

\section{References}

Abdulla, A. R., Nada, F. K., \& Nadhim, K. I. (2016). Natural Radioactivity and Associated Dose Rates in Soil Samples in the Destroyed Fuel Fabrication Facility, Iraq. Interna- 
tional Journal of Physics, 4, 50-54.

Aguko, W., Kinyua, R., \& Ongeri, R. (2013). Assessment of Radiation Exposure Levels Associated with Gold Mining in Sakwa Wagusu, Bondo District, Kenya. Proceedings of the 8th JKUAT Scientific, Technological and Industrialization Conference, Juja-Kenya, 1415 November, 221-228.

Al-Hamarne, I. F., \& Awadallah, M. I. (2009). Soil Radioactivity Levels and Radiation Hazard Assessment in the Highlands of Northern JORDAN. Radiation Measurements, 44, 102-110. https://doi.org/10.1016/j.radmeas.2008.11.005

Avwiri, G. O., Ononugbo, C. P., \& Egieya, J. M. (2013). Evaluation of Natural Radionuclide Content in Surface and Ground Water and Excess Lifetime Cancer Risk Due to Gamma Radioactivity. Academic Research International, 4, 636.

Qureshi, A. A., Tariq, S., Ud Din, K., Manzoor, S., Calligaris, S., \& Waheed, A. (2014). Evaluation of Excessive Lifetime Cancer Risk Due to Natural Radioactivity in the Rivers Sediments of Northern Pakistan. Journal of Radiation Research and Applied Sciences, 7, 438447. https://doi.org/10.1016/j.jrras.2014.07.008

Beretka, J., \& Mathew, P. J. (1985). Natural Radioactivity of Australian Building Materials, Industrial Wastes and By-Products. Health Physics, 48, 87-95. https://doi.org/10.1097/00004032-198501000-00007

Cember, H. (1996). Introduction to Health Physics (3rd ed.). New York: McGraw-Hill.

EPA (1995). Representative Sampling Guidance, Vol. 1: Soil. EPA/540/R-95/141, Washington DC: EPA.

Harb, S., Din, K. S., Aaady, A., \& Mostaf, M. (2010). Activity Concentration for Surface Soil Samples Collected from Armant, Qema, Egypt. In Proceedings of the 4th Environmental Physics Conference, Hurghada, 49-57.

Hassan, S. F., Mahmoud, M. A. M., \& El-Rahman, M. A. (2016). Effect of Radioactive Minerals Potentiality and Primordial Nuclei Distribution on Radiation Exposure Levels within Muscovite Granite, Wadi Nugrus, Southeastern Desert, Egypt. Journal of Geoscience and Environment Protection, 4, 62-78. https://doi.org/10.4236/gep.2016.43006

IAEA TECDOC 1363 (2003). Guidelines for Radioelement Mapping Using Gamma Ray Spectrometry Data. Vienna: International Atomic Energy Agency.

IAEA TECDOC 486 (2019). Guidelines on Soil and Vegetation Sampling for Radiological Monitoring. Vienna: International Atomic Energy Agency.

ICRP (1990). Radiation Protection. 1990 Recommendations of the International Commission on Radiological Protection. ICRP Publication 60, Oxford: Pergamon.

ICRP (2000). Protection of the Public in Situations of Prolonged Radiation Exposure. ICRP Publication 82, Ann. ICRP, 29 (1-2), Oxford: Pergamon.

ICRP (2007). The 2007 Recommendations of the International Commission on Radiological Protection. ICRP Publication 103. Annals of the ICRP, 37, 2-4.

Krieger, V. R. (1981). Radioactivity of Construction Materials. Betonwerk Fertigteil Technology, 47, 468-473.

Lu, X. W., \& Zhang, X. L. (2006). Measurement of Natural Radioactivity in Sand Samples Collected from the Baoji Weihe Sands Park, China. Environmental Geology, 50, 977-982. https://doi.org/10.1007/s00254-006-0266-5

Monika, S., Leszek, P., \& Marcin, Z. (2010). Natural Radioactivity of Soil and Sediment Samples Collected from Postindustrial Area, Poland. Polish Journal of Environmental Studies, 19, 1095-1099.

Mustapha, A. O. (1999). Assessment of Human Exposures to Natural Sources of Radiation in 
Kenya. PhD Thesis, Nairobi: University of Nairobi. https://doi.org/10.1093/oxfordjournals.rpd.a032637

Obed, R. I., Farai, I. P., \& Jibiri, N. N. (2005). Population Dose Distribution Due to Soil Radioactivity Concentration Levels in 18 Cities across Nigeria. Journal of Radiological Protection, 25, 305. https://doi.org/10.1088/0952-4746/25/3/007

Qureshi, A. A., Tariq, S., Din, K. U., Manzoor, S., Calligaris, C., \& Waheed, A. (2014). Evaluation of Excessive Lifetime Cancer Risk Due to Natural Radioactivity in the Rivers Sediments of Northern Pakistan. Journal of Radiation Research and Applied Sciences, 7, 438447. https://doi.org/10.1016/j.jrras.2014.07.008

Raghu, Y., Ravisankar, A., Chandrasekaran, P., et al. (2017). Assessment of Natural Radioactivity and Radiological Hazards in Building Materials Used in the Tiruvannamalai District, Tamilnadu, India, Using Statistical Approach. Journal of Taiban University for Science, 11, 523-533. https://doi.org/10.1016/j.jtusci.2015.08.004

Singh, S., Mehra, R., \& Singh, K. (2005). Seasonal Variation of Indoor Radon in Dwellings of Malwa Region, Punjab. Atmospheric Environment, 39, 7761-7767.

https://doi.org/10.1016/j.atmosenv.2005.08.030

Survey of Kenya (2017). Modified. https://lands.go.ke

Taskin, H., Karavus, M., Ay, P., Topuzoglu, A., Hidiroglu, S., \& Karahan, G. (2009). Radionuclide Concentrations in Soil and Lifetime Cancer Risk Due to Gamma Radioactivity in Kirklareli, Turkey. Journal of Environmental Radioactivity, 100, 49-53. https://doi.org/10.1016/j.jenvrad.2008.10.012

Tzortzis, M., \& Tsertos, H. (2004). Determination of Thorium, Uranium and Potassium Elemental Concentrations in Surface Soils in Cyprus. Journal of Environmental Radioactivity, 77, 325-338. https://doi.org/10.1016/j.jenvrad.2004.03.014

UNSCEAR (1993). Sources and Effects of Ionizing Radiation. United Nations Scientific Committee on the Effects of Atomic Radiation, Report to the General Assembly, with Scientific Annexes, New York: United Nations Publication.

UNSCEAR (2000). Sources and Effects of Ionizing Radiation. United Nation Scientific Committee on the Effects of Atomic Radiation Sources to the General Assembly with Annexes, Effects and Risks of Ionizing Radiation, New York: United Nations Publication.

UNSCEAR (2008). Sources and Effects of Ionizing Radiation. United Nation Scientific Committee on the Effects of Atomic Radiation Sources to the General Assembly with Annexes, Report to the General Assembly, with Scientific Annexes, New York: United Nations Publication. 